\title{
'Struck from all sides' - Reliving the Lived Experiences of Immigrant Youths in the Context of Mafiarised Religions: Towards a Rehumanisation of Theology
}

\author{
Bekithemba Dube \\ ORCID iD: https://orcid.org/0000-0003-4327-7838
}

\section{Omodan Isaiah Bunmi \\ ORCID iD: $\underline{\text { https://orcid.org/0000-0002-9093-3108 }}$}

\section{Abstract}

In this paper, we interrogate various trajectories in relation to religious mafia, as faced by undocumented immigrant Zimbabwean youth in the city of Johannesburg, South Africa. One of the migration variables is the emergence of various religious movements that align themselves with oppressed and marginalised immigrant communities, in particular youth,.. Religion has come to offer solace to migrant youth, since it is has the impetus to usher in 'hope' and provide quick solutions in the face of a variety of ambivalences and ambiguities. While this religious task may be noble, and desirable, many migrant youth have fallen victim to religious mafia movements, In this light, the paper is underpinned by decoloniality theory, which seeks to name, challenge and emancipate the oppressed, and reconstruct a rehumanised theology. The participatory action research method was used to collect data from 15 youths. The findings indicate that so-called mafiarised religions have exacerbated the plight of undocumented migrants, by offering false hope, false protection, and empty promises of employment. We conclude the paper by arguing that there is a need to reconstruct a theology that rehumanises oppressed migrant youths, and deliberately challenge religious mafia.

Keywords: mafia, immigrants, undocumented youth, decoloniality, church, rehumanisation 


\section{Introduction}

Migrants' narratives have occupied scholarly space for a long time, and offer divergent perspectives; indeed, it has become a global phenomenon that leaves few countries unaffected (Minter 2011). The phenomenon of migration presents in a multiplicity of guises. It is a complex phenomenon that is among the most hotly contested themes of contemporary public debates and discussions (Lehohla 2011), especially in the context of economic turmoil. Cognisant of various perspectives, and the contested nature of migration, we narrow our focus to issues affecting migrant youth from Zimbabwe in the context of religious mafia. While the reasons for migration can be debated, they are often presented in the form of accusations lacking valid and empirical evidence. Youth are forced to migrate in search of education, work, marriage and, more commonly, better economic opportunities (Crivello 2011). However, in their pursuit of these opportunities, migrant youth face various challenges, such as racism, discrimination, xenophobic attacks and hate crimes (Minter 2011; Sigamoney 2018; United Nations 2015). Deprived migrant youth continue to suffer and lack unprotection, and are often alone. Consequently, they are exposed to social pathologies, including traffickers and other people who abuse and exploit them (United Nations Children's Fund 2017). Consequently, migrant youth turn to religion, or continue with their religion, as source of comfort and hope; however, even within these supposedly safe religious contexts, they are exploited.

Despite all the problems stated above, migration continues, both within countries and internationally. Migration has long been one of the options for people who seek to achieve a better life, or to escape unacceptable hardships (Minter 2011). Thus, religion, in some contexts, plays a pivotal role in the transaction (from their home land to a foreign one) and in neutralisation processes.

\section{Migration, Religion and Criminality}

In migration narratives, religion has always played a crucial role; as a resilience factor, it is one of the variables that plays a role in survival, especially in contexts of oppression, inequality and marginalisation. This is because, when people migrate for any length of time, they take their religions with them (Spickard \& Adogame 2010). Thus, religious leaders and rituals generally play a significant role in ensuring a safe passage for migrant youth, and in assisting 
youth to acquire the legal status of migrants (Engh 2018). Various religious groups have played crucial roles in providing migrant youth with shelter, food, and clothing, especially in contexts characterised by xenophobia - one example is the City Methodist Church in Johannesburg (Chisale 2016). However, while assisting migrants may be a noble idea that is doable and appreciated, some opportunistic and unscrupulous religious people have taken advantage of migrants' vulnerability to advance criminal elements using religion as a cover. We use the term 'religious mafia' in our discussion to refer to this phenomenon. The term will be defined in greater detail below. The mafia in the church takes advantage of migrant youth, which dehumanises them in the process. Thus, there is a need for a rehumanising theology, as a counter-hegemony strategy to deal with religious mafia. Informed by the foregoing argument, we will focus on religious mafia activities that migrants are subjected to.

\section{Situating the Importance of the Study}

We believe our study fills a gap by problematising religious mafia within the space of decoloniality, to ignite a need for a rehumanising theology that cares for sojourners. We came to this conclusion after reviewing a variety of literature within the space and conversation of youth, migration and religion. Consequently, we report on a study by Magezi (2017), which assessed theological-ecclesiological responses and approaches to migration challenges to ascertain lacunae within Christian ministry engagement. Magezi promotes theological research that is central to migration studies, and which is conducted in a manner that demonstrates that theology transcends spiritual reflection, to include practical psychosocial, emotional, economic and other dimensions. Research by Martin (2004) responds to two major issues: how migration affects development in sending countries, and how development, in the form of closer economic integration between developing and developed countries, affects migration flows. Central to his argument is that migration can be a tool for development, and that development can affect migration patterns. A district-level impact study conducted by Kollamparambil (2017) in South Africa found heightened income inequality as a result of migration. The study's findings showed that a better understanding is needed of the role played by migrants in the labour markets of the receiving community, and whether migration contributes to the labour market participation rate, employment 
rates, informalisation, and entrepreneurship in the migrant receiving areas.

Hiropoulos (2017) observed that, in the midst of xenophobic violence, foreign nationals struggle to access justice services and police protection. Manda and Settler (2010) studied religion and faith in the migratory process, to consider and understand how migration changes people, religious institutions, beliefs and practices, and impact migrant women. These studies, in general, found various trajectories associated with migration. Despite inadequate evidence, locals often believe that foreigners are hired by local employers, reducing the employment levels of locals. It appears that the contributions of migrants in creating South Africa's so-called rainbow nation are often ignored.

This paper is unique in migration and religious discourses, in that it focuses on migrant youth in Johannesburg against the backdrop of the involvement of religious mafia movements. Furthermore, this paper interrogates migrant youths through the lens of decoloniality and presents the argument that, while traditional churches have been hubs or cities of refugees, other religious movements have emerged that, instead of offering protection to youth, exacerbate their plight by offering false hope of a better future for these young migrants, and falsely promise protection and escape from immigration officers. The false hope becomes a dehumanising experience for the youth, who are struck from all sides, that is, by their country of origin, by the receiving country and, in this case, by religious movements.

Cognisant of the foregoing argument, the paper presents lived experiences of migrant youth in Johannesburg, South Africa. It argues that a decolonial approach to religious narratives can undo the work of the mafia, which, in this case, worsens the plight of migrant youth. In doing so, we respond to the call by Bottoms et al. (1995: 109) that '[i]n the long run, society should find ways to protect people [against] religion-related abuse, and help religion evolve in the direction of the better treatment of people'.

This paper should not be construed as saying that all churches have caused suffering for migrant youth in South Africa. In fact, various studies indicate that churches have been and continue to be instrumental in providing comfort, peace and protection for migrants. While this is true for many churches, and is applauded, there is a side of religion that has not been problematised, among which mafiarised movements, which, instead of protecting migrants, take advantage of and exploit youth, in particular. Thus, this paper focuses on these movements through the lens of decoloniality, to 
unmask and challenge exploitation premised on religion. The paper is arranged as follows: a definition of terms will be followed by a decoloniality theoretical framing, the methodology applied, and then, findings will be presented and discussed.

\section{Definition of Operational Terms}

Religious mafia, as defined and used in this paper, refers to praxis and discourses in a religious context that promote social pathologies, such as oppression, inequality and exploitation. In fact, the term mafiarisation originates from a group of criminals known as the mafia, which is known for using drugs and dangerous weapons to commit various crimes (Garzon 2008; Paoli 2007; 2008). As used in this context, it refers to acts of criminality that are practiced under the auspices of religion.

Migrants is a neutral term for a group of people or individuals who have in common a lack of citizenship attachment to their host country (United Nations High Commissioner for Refugees 2015). In this paper, it refers to youth, in particular undocumented youth in Johannesburg, who suffer various trajectories inflicted by certain sectors of society. Using the term does not imply that the lack of documentation is right, or that we applaud the criminal behaviour of some youths - not by any measure of the imagination. Instead, the focus of the paper is on those youths who, due to their status of being undocumented, fall prey to criminal elements disguised as religion.

Rehumanisation theology, in the context of religion and migration, refers to religious teachings that must be upheld by decolonial churches that seek to increase the ontological density of the oppressed and to eradicate coloniality. In short, it is a theology that seeks to ensure that human beings are treated equally and fairly, despite their country of origin, status, or race, among many other variables that may undermine a person's wellbeing.

\section{Theoretical Framing: Decoloniality}

Decoloniality is used in this paper as the lens to interrogate youth migrants and religious mafia in South Africa. Decoloniality theory refers to a struggle and a commitment to challenge and reformulate the communicational scientific discourse, from criticism of the mediating power of Anglo-American hegemonic thinking, to a native cultural paradigm (Huerfano et al. 2016). At its 
core, decoloniality rejects modernity, which is at the oppressed and exploited side of the colonial difference, in favour of a decolonial liberation struggle, in order to achieve a world beyond Eurocentric modernity (Grosfoguel 2011). Doing so 'entails the rehumanisation of the dehumanised and the courage to care and to love' (Mpofu 2017:4). Furthermore, as proposed by Mignolo (2009), it evokes a political and prophetic epistemic delinking, as an alternative to (re)imagining and building a democratic, just, and non-imperial religious community. We consider it relevant for this paper, because it is about shifting the geography of reason, with a clear locus of enunciation (Sithole 2014), and evoking a dehumanising theology. Decoloniality is a theory that opposes coloniality of being, power and knowledge (Mpofu 2017).

For us, religious mafia presents a new form of coloniality, one that must be challenged. The decoloniality project seeks to unmask, challenge and undo the coloniality of migrant youth within the context of religion. This idea is buttressed by Ndlovu-Gatsheni (2013), who argues that churches and universities in Africa are sites for the reproduction of coloniality. With respect to religious mafia, our thinking on decoloniality is in agreement with that of Oelofsen (2015:130), who points out that, 'to claim that the colonial project stops having an impact on the newly decolonised country and its citizens, is to misunderstand how deeply the colonial project affected these countries and their citizens'. This theory is pertinent to this paper, as it is a theory that allows the retelling of the history of humanity, and [retelling of] knowledge from the vantage point of those epistemic sites that received the 'darker side' of modernity, including retelling the story of knowledge generation that involves borrowings, appropriations, epistemicides, and denials of the humanity of other people, as part of the story of science (Ndlovu-Gatsheni 2013:13). In this case, it involves telling the story of the lived experiences of migrant youth and their subjection by mafiarised religious movements.

\section{Methodology: Participatory Action Research and Data Analysis}

To generate data, we used participatory action research (PAR), because it is a methodology associated with disadvantaged members of society, and the goal was to unlock their narratives to evoke strategies to liberate them in the context of religious mafia. In addition, PAR is relevant to this paper, because it seeks to 'identify the rights of those concerned by the research, and empowering 
people to set their own schemas for research and development, thereby giving them tenure over the process' (Cornwall \& Jewkes 1995:1674). PAR responds to a reality that declares that conditions of injustice are not natural, but are produced, and can, therefore, be challenged (Loewenson et al. 2014:14). In short, we used PAR for this research because it is a community-oriented research and action for social change to promote marginalized communities, where the quest is to unearth the causes of social inequality and provide solutions to the identified problems' (Williams \& Brydon-Miller 2004:245). A total of 15 youth, between the ages of 18 to 21 years, participated in the study. We used the snowball sampling approach, for which networking and referrals are central, which was essential for a sensitive study like this one (Parker et al. 2019). In applying PAR, we conducted three focus group discussions, guided by two questions: What experiences and challenges do youth migrants face in churches? How can the church regain its position as a hub, and as a place of refuge, through a dehumanising theology? The data generated was analysed according to the seven steps of Laws et al. (2003):

Step 1: Read and reread all the collected data: The data from focus group discussions were read and reread to get the essence of the lived experiences of the migrant youths.

Step 2: Draw up a preliminary list of themes arising from the data: Major issues and themes were identified and arranged according to the research question of the study.

Step 3: Reread the data: By rereading the data, we checked if the themes we had identified corresponded with what the participants had said, and with the research questions.

Step 4: Link the themes to quotations and notes: The themes that had emerged from the data were linked to various scholarly views.

Step 5: Peruse the categories of themes to interpret them: During the interpretation of the data, we remained cognisant of the research questions.

Step 6: Design a tool to help discern patterns in the data: This step enabled us to determine patterns in the data.

Step 7: Interpret the data and derive meaning: We identified themes, which became the subheadings of this paper. 
This paper adhered to ethical standards, including protection of the participants, permitting voluntary withdrawal, and obtaining informed consent to participate in the research. The names used in the paper are pseudonyms, to protect the identities of the participants. To ensure validity of the data, we did member checking. In this process, we sent the identified themes to the participants to verify that the data corresponded to their lived experiences (Birt et al. 2016:1802; Bygstad \& Munkvold 2007:1; Gunawan 2015:10).

\section{Trajectories of Migrant Youths in Johannesburg}

In this section, we present findings that speak to the first research question: What experiences and challenges do youth migrants face in churches? In discussing the trajectories that emerged, we realised that youth migration intersects with almost every other issue affecting people's lives, which can either create opportunities or contribute to crises (Minter 2011). The first trajectory we discuss is the exploitation of immigrant youths in churches.

\section{Exploitation of Immigrant Youths in Churches}

It emerged from many participants' responses that some religious leaders and movements take advantage of migrant youths' lack of documentation, to manipulate and control them under the pretext of sourcing documents and providing safety. During this discussion, Nomvula said,

I joined the church with the hope that my suffering as a migrant will end. My friend had invited me to church to try his prophet to assist with bad luck but when I was there, I realised that it was all about making the prophet rich.

Martha said,

Some churches here in Jozi exists to take advantage of the migrants. They promise too many things such as promotion and protection at workplace, but one waits forever to have the promises fulfilled, yet we [are] made to pay always.

From the participants' responses it became clear that, in exploiting the youth, 
criminality has found a space in some religious movements. Dube et al. (2017) lament religious exploitation and argue that it is necessary to set parameters within which religion should be regulated. However, Banda (2019) seems to disagree with Dube et al (2017) about the regulation of religion, arguing that regulation defeats the purpose of the church being autonomous. While Banda presents a reasonable argument, we are of the view that regulation should target criminality within religion, while other aspects of religion should continue to be controlled within the religious space itself, as long as the church promotes human good and humanisation.

\section{Abuse through Strategic Distancing}

The research revealed that most of the youth succumb to what is referred to by Chidester (2003) as strategic distancing. The migrant youth who participated in the study revealed that mafiarised religion strives to separate individuals from their families to facilitate control. This separation undermines family unity and makes youth more susceptible to control. During the group discussion, Zama noted,

Most churches here play with our minds, they often give us prophecies that we are bewitched by our family members and friends, making it easier for people to believe them for protection, only for one to discover that there is no witchcraft at all but the damage would [already] have been done.

Zanele echoed this experience, by explaining that,

I met a prophet who told me I was being bewitched by my mother, so for years I hated my mother thinking she was bewitching me, but I become suspicious when the prophet demanded money from me every month. I was told I will have misfortune everywhere if I do not do what he says. Then I saw that this is [was] a scam.

After analysing the participants' stories, it became clear that, in contrast to the norm of family building that is common in most churches' traditions, mafiarised religious movements strive to divide and distance family members, which isolates youth and makes them easy targets. This strategy may result in many 
youth becoming destitute, because they lack family support structures. Consequently, we argue that strategic distancing, when used by religion to commit criminal acts, means the religion has mafia-like tendencies. This form of religion must be challenged. It is our hope that decoloniality-oriented churches can exorcise religious narratives and praxis that promote mafia tendencies. In this case, we argue for a rehumanising theology, as a means to bring comfort and healing to migrants who have suffered under such religious mafia.

\section{Financial Exploitation of Youth Migrants for Protection and Promotion}

Some undocumented youth face challenges relating to financial exploitation by religious movements. Speaking during the discussion, Noza articulated,

I know one friend of mine who has since passed on, she gave all her salary to the pastor as means for good health, promotion and escape from law enforcers. However, when she died in pain and hurt and [they] never visited her while in hospital and in [did not attend] her funeral, despite 'eating' all her money.

Zaza added,

Most of the pastors in the church I attended will not phone until its month-end and when they call, they make demands as if it's their money, if you don't, you are threatened with failure and misfortune.

In light of these participants' experiences, Wafawarova (2015) is right to argue that the preaching of so-called prosperity prophets has the ironic effect of keeping people in poverty. While Mpofu (2018) rightly points out that the hostility of some churches towards migrants indicates that the church views them as second-class citizens. Our argument is that the church has a biblical mandate and should not be seen to promote a dichotomy between a country's citizens and its migrants. Thus, we argue that a rehumanising theology is essential to 'rewire' both migrants and citizens to understand that nationality as understood and conceptualised by society is not a natural state order, but a social construct which is the direct impact of colonisation. What is also disturbing, is that some members of the religious mafia are also migrants and 
themselves undocumented, yet they inflict pain on fellow migrants. This speaks to the need to re-examine theology in Africa, especially with a decoloniality approach. In short, financial exploitation of migrants within the religious space must be unmasked and challenged, to produce a world order free of exploitation.

\section{Sexual Exploitation by Church Leaders}

During the focus group discussion, it emerged that some religious leaders take advantage of and sexually abuse youths, knowing that they are undocumented and desperate. This sort of abuse is not new in the narrative of migration. While abuse is not new, it becomes a grave concern when practised within religious spaces (Minter 2011). Most of the migrants in Johannesburg face accommodation problems, largely because housing is expensive. Mafiarised religious spaces take advantage of this need, and sexually abuse youths in exchange for accommodation. Mondli reported,

[The] high cost of living and accommodation lead many youths to fall in the hands of prophets, who offer accommodation as long he still enjoys sexual favours from the youths. Once the affection is gone, the youth are mistreated, until they leave. This is unfortunate, especially when done by religious leaders.

It is clear that sexual exploitation is one of the trajectories faced by youth. This has been a common phenomenon throughout religious history. Vivid examples are the Jonestown incident in the United States of America in 1978 (Hall et al. 2000:43; Larsen 2010:44) and, more recently, the abuses by the Seven Angels Ministry leaders in Ngcobo, Eastern Cape (Dube 2019). From the discussion, we conclude that sexual exploitation happens through mental incapacitation, which is described by Quijano (2008:182) as 'a mental category of modernity', with the agenda to distance, exploit and strike helpless migrant youth.

Informed by these trajectories, we moved on to the second research question: How can the church regain its position as a hub, and as a place of refuge, through a dehumanising theology? Our proposition is that there is a need for a rehumanising theology to eliminate criminality committed by religion. 


\section{Rehumanising Theology: What can be Done about Religious Mafia in the Migration Narrative?}

We agree with Sithole (2014) that there is a need to rethink, and even, to go beyond thinking, to the point of exhaustion, to avoid coloniality of the mind, used by most mafiarised religious groups. As scholars of religion who are oriented to social justice, we have an obligation to suggest ways in which religion in contested spaces can regain its trust and identity among the oppressed, including migrant youth in Johannesburg. Our first suggestion relates to the need for churches to embrace a rehumanising theology, and to fight the colonial tendencies portrayed by religious mafia.

\section{Evoking Rehumanising Theology}

In the face of mafiarised religion in the context of migration narratives, we submit that there is a need to rethink theology that is informed by the decoloniality notion of epistemic disobedience, to rehumanise migrant youth. A decolonial resistance against churches that covertly or overtly exploit disadvantaged members of society, including migrant youths, can assist to resolve the challenges under discussion. Rehumanising theology emphasises the need to respect human rights. We are firmly of the view that human rights are not reserved only for South African citizens: Anyone who is in a state's territory or within its jurisdiction must be treated without discrimination, regardless of their administrative status or circumstances (United Nations 2015). Thus, respecting only the rights of citizens, and ignoring migrants' rights, represents a minimalistic approach to democracy. Informed by decoloniality, we agree with Mashau (2018), that African religious groups should embrace care and humanity as a matter of urgency. This is essential, because migrants in both regular and irregular situations are acutely vulnerable to violence and abuse by private and state actors and, even more at the hands of the leaders of mafiarised religions. The United Nations (2015) argues that abuse, irrespective of its source or cause, must be confronted as a matter of urgent priority.

Thus, this paper argues for a rehumanising theology that, when embraced within decoloniality, will lead to religious groups being able to tease out and evoke discourses and narratives that can benefit migrant youth or other disadvantaged members of society. It is our submission that churches should be harbingers of change through respecting human rights, and advocates for 
protecting the rights of all migrants (United Nations 2015). Thus, no church theology that ignores these rights can possibly help Africans escape the fetters of oppression, inequality and marginalisation, which, in this case, is caused by religious mafia (Kaunda 2016). By arguing this way, we are not being fundamentalist; instead, we argue for shifting the geography of reason with a clear locus of enunciation (Sithole 2014), which will enable liberation of thinking and encourage a delinking from religious imperialism (Tlostanova \& Mignolo 2009:22) and the mafia. In short, churches, in the context of migrant youth, should play a proactive role to 'look at, expose, and question hegemony, traditional power assumptions held about relationships, groups, communities, societies, and organisations to promote social change' (Given 2008:140).

\section{Educating Youth Migrants about their Rights}

We are aware that, the world over, the rights of migrants are often marginalised, both in migrant-receiving and migrant-sending countries (Minter 2011). The need to educate youths on their rights is essential - doing so correlates with best practices of a democratic state. This claim is confirmed by the World Council of Churches (2017), which argues that the church should help to ensure that everyone knows about the rights of children and youths. Education and training on human rights will impact communities' social fabric and their ability to steer themselves toward desired futures (Eversole 2001). We agree with the observation made by the Church of England (2017), that the church should strive to create and maintain environments that are safer for all, that promote well-being, that prevent abuse, and that create nurturing, caring conditions within the church for children, young people and vulnerable adults. This education should not only be for migrant youths, but for all of South Africa and beyond. With a lens of decoloniality, educating the youth on rights becomes a move towards dismantling the hegemonic discourse that questions the humanity of all those who do not belong to the locus of enunciation (and the geopolitics of knowledge) of those who assign the standard of classification, and assign to themselves the right to classify others (NdlovuGatsheni 2013).

With this proposition, we hope that ontological pluralism, as a reality, is understood (Ndlovu-Gatsheni 2013), appreciated and respected, regardless of nationality, not only from the vantage point of oppressed migrant youths, but also from the perspective of the oppressor, and that it will serve as a 
rehumanising process for both. We conclude this point by arguing that protecting the interests of migrants requires a rights-based approach that defends the applicability of fundamental human rights to migrants, and also protects and expands the right to migrate (Minter 2011). The church, through its divine mandate, is one of the best available variables to provide such a service. We affirm that the role of religion is not limited to meaning making and coping strategies, but also includes producing and maintaining transnational networks of relationships and human rights among migrant youth (Settler \& Engh 2018).

\section{Exhorting Youths to Legalise their Presence}

In this research, we noted that many of the youth in Johannesburg who participated in this study are not in South Africa legally. It means that many youth do not have travel documents, thus, making them susceptible to mafia groups, who take advantage of undocumented members of society. To address the challenge of the abuse of undocumented youth, we are of the view that the church must take an active role in dismantling the mentality of living as undocumented. For security and national budget purposes, governments are entitled to know who are within their borders. The church should help in providing relevant information for documentation. Documenting migrant youth will limit social trajectories associated with being undocumented; being documented is part of the process of rehumanising people; the youths become responsible and ensure that their residence in a country is proper and legal.

\section{Conclusion}

In this paper, we discussed various challenges faced by migrant youth in Johannesburg. The research revealed that youths escaped poverty from various countries in the hope of finding greener pastures in South Africa. However, the hope is often quashed when migrants are exposed to religious mafia in the new country. We conclude that migrant youths are being struck from all sides: in their country of origin, as well in foreign spaces. To this end, our paper was couched in decoloniality theory, to argue for the need to rehumanise a theology that emphasises care, justice, love and respect for all people, regardless of nationality. It is through these qualities that we, as Africans, can produce a world order that confronts coloniality of being and, in the process, promote the 
ontological density of migrant youth. We end the paper by recommending that religious groups be proactive in promoting human rights, teaching human rights and sensitising migrants about the importance of being documented.

\section{References}

Banda, C. 2019. Redefining Religion? A Critical Christian Reflection on CRL Rights Commission's Proposal to Regulate Religion in South Africa. Verbum et Ecclesia 40,1: a1948.

https://doi.org/10.4102/ve.v40i1.1948

Birt, L., S. Scott, D. Cavers, C. Campbell \& F. Walter 2016. Member Checking: A Tool to Enhance Trustworthiness or Merely a Nod to Validation. Qualitative Health Research 26,12: 1802 - 1811.

https://doi.org/10.1177/1049732316654870 PMid:27340178

Bottoms, B.L., P.R Shaver, G.S. Goodman \& J. Qin 1995. In the Name of God:

A Profile of Religion-Related Child Abuse. Journal of Social Issues 51,1:

85 - 111. https://doi.org/10.1111/j.1540-4560.1995.tb01325.x

Bygstad, B. \& B.E. Munkvold 2007. The Significance of Member Checking

Validation in Qualitative Analysis: Experiences from a Longitudinal Case

Study. Proceeding of the $40^{\text {th }}$ Hawaii International Conference on System

Sciences. Available at: https://core.ac.uk/download/pdf/52058218.pdf

(Accessed on 31 March 2018.) https://doi.org/10.1109/HICSS.2007.553

Chidester, D. 2003. Salvation and Suicide. Jim Jones: The Peoples' Temple and Jonestown. Indiana: Indiana University Press.

Chisale, S.S. 2016. Bishop Paul Verryn's Pastoral Response Towards

Unaccompanied Refugee Minors. HTS Theological Studies 72,2: 1 -

8. https://dx.doi.org/10.4102/hts.v72i2.3411

Church of England 2017. Promoting a Safer Church: Safeguarding Policy

Statement for Children, Young People and Adults. London: Church House

Publishing.

Cornwall, A. \& R. Jewkes 1995. What is Participatory Action Research? Social Science and Medicine 41:1666 - 1676.

https://doi.org/10.1016/0277-9536(95)00127-S

Crivello, G. 2011. 'Becoming Somebody': Youth Transitions through Education and Migration in Peru. Journal of Youth Studies 14,4: 395 411. https://doi.org/10.1080/13676261.2010.538043 
Dube, B. 2019. Conundrum of Religious Mafia and Legislation in South Africa: When does Religion become a National Threat? Reference to the Seven Angels Ministry. Verbum et Ecclesia 40,1: a1864. https://doi.org/10.4102/ve.v40i1.1864

Dube, B, M.M. Nkoane \& D. Hlalele 2017. The Ambivalence of Freedom of Religion and Unearthing the Unlearnt Lessons of Religious Freedom from the Jonestown Incident: A Decolonial Approach. Journal of the Study of Religion 30: 330 - 49.

https://doi.org/10.17159/2413-3027/2017/v30n2a14

Engh, M.H. 2018. Because I Know God Answers Prayers: The Role of Religion in African-Scandinavian Labour Migration. Alternation Special Edition 22: 57 - 80. https://doi.org/10.29086/2519-5476/2018/sp22a4

Eversole, R. 2001. Keeping Youth in Communities: Education and Outmigration in the South West. Rural Society 11,2: 85 - 98.

https://doi.org/10.5172/rsj.11.2.85

Garzon, J.C. 2008. The Criminal Networks in Mexico, Brazil and Colombia. Washington: Woodrow Wilson.

Given, L.M. (ed.) 2008. The Sage Encyclopaedia of Quantitative Research Methods. London: Sage. https://doi.org/10.4135/9781412963909

Grosfoguel, R. 2011. Decolonizing Post-Colonial Studies and Paradigms of Political Economy: Transmodernity, Decolonial Thinking and Global Coloniality. Transmodernity: Journal of Peripheral Cultural Production of the Luso-HispanicWorld 1: 1 - 38.

Gunawan, J. 2015. Ensuring Trustworthiness in Qualitative Research. Nursing Journal 1,10: 10 - 11. https://doi.org/10.33546/bnj.4

Hall, J.R., P.D. Schuyler \& S. Trinh 2000. Apocalypse Observed: Religious Movements and Violence in North America, Europe and Japan. New York: Routledge.

Hiropoulos, A. 2017. Migration and Detention in South Africa. A Review of Applicability and Impact of Legislative Framework on Foreign Nationals. African Policing Civilian Oversight Forum. Available at: www.apcof.org/up-context/uploads/0-18-migration-and-detention-insouth-africa

Huerfano, H.E., F.S. Caballero \& C.D. Rojas 2016. Towards an Epistemology of the South: Decoloniality, Informative Knowledge Power and the New Latin-American Community. Chasqui: Latinoamericana de Comunicacion. 
Kaunda, C.J. 2016. Towards an African Ecogender Theology: A Decolonial Theological Perspective. Stellenbosch Theological Journal 2,1: 177 - 202. http://dx.doi.org/10.17570/stj.2016.v2n1.a09

Kollamparambil, U. 2017. Labour Market Impact of Internal In-migration. A District Level Analysis of South Africa. Pretoria: Economic Research Southern Africa. (ERSA working paper 667.)

Larsen, L.E. 2010. What Went Wrong with the People's Temple? A Closer Look at Jim Jones and the People's Temple. Stavanger: School of Mission and Theology.

Laws, S., C. Harper \& R. Marcus 2003. Research for Development. London: Sage. https://doi.org/10.4135/9781849209786

Lehohla, P. 2011. Census 2011: Migration Dynamics in South Africa. Pretoria: Statistics South Africa. (Report No. 03-01-79.)

Loewenson, R., A.C. Laurell, C. Hogstedt, L. D’Ambruoso \& Z. Shroff 2014. Participatory Action Research in Health Systems: A Methods Reader.

Harare: International Development Research Centre.

Magezi, C. 2017. Migration Crisis and the Church: A Response to Lacunae and

Considerations for Christian Ministry Engagement. Verbum et Ecclesia 38,1: a1671.

https://doi.org/10.4102/ve.v38i1.1671

Manda, P. \& F. Settler 2010. Contestations of Self and Other in Researching Religion, Gender and Health among Migrant Women. Alternation, Special Edition 22: 119 - 141.

https://doi.org/10.29086/2519-5476/2018/sp22a7

Martin, P.L. 2004. Migration and Development: Towards Sustainable Solutions. Geneva: International Institute for Labour Studies. (Discussion Paper. Decent Work Research Programme DP/153/2004.) Available at: www.ilo.org/wcmsps/groups

Mashau, T.D. 2018. Unshackling the Chains of Coloniality: Reimagining Decoloniality, Africanisation and Reformation for a Non-racial South Africa. HTS Teologiese Studies/ Theological Studies 74,3: 4920. https://doi.org/10.4102/hts.v74i3.4920

Mignolo, W.D. 2009. Epistemic Disobedience, Independent Thought and Decolonial Freedom. Theory, Culture \& Society 26,7-8: 1 - 23. http://doi.org/10.1177/0263276409349275

Minter, W. 2011. African Migration, Global Inequalities and Human Rights. Connecting the Dots. Uppsala: Nordiska Afrikainstitutet. 
Mpofu, B. 2018. Church as Hostile, Host or Home: Perspectives on the Experiences of African Migrants in South Africa. Alternation, Special Edition 22: 103 - 118. https://doi.org/10.29086/2519-5476/2018/sp22a6 Mpofu, W. 2017. Decoloniality as a Travelling Theory: Or what Decoloniality is Not. Seminar presented at Wits Institute for Social and Economic Research, University of the Witwatersrand, 7 August 2017. Available at: www.wiser.wits.ac.za/systems/files/seminar/mpofu2017/pdf (Accessed on 20 April 2018.)

Ndlovu-Gatsheni, S.J. 2013. Why Decoloniality in the 21st Century. The Thinker for Thought Leaders 2013,48: 10 - 16.

Oelofsen, R. 2015. Decolonisation of the African Mind and Intellectual Landscape. Phronimon 16,2: 130 - 146. https://doi.org/10.25159/2413$3086 / 3822$

Paoli, L. 2007. Organised Crime in Italy: Mafia and Illegal Markets Exceptions and Normality. Dordrecht: Springer.

https://doi.org/10.1080/01402380701500330

Paoli, L. 2008. Mafia and Organised Crime in Italy: The Unacknowledged Successes of Law Enforcement. West European Politics 30,4: 854 - 880. Parker, C., S. Scott \& A. Geddes 2019. Snowball Sampling. In Atkinson, P.,

S. Delamont, A. Cernat, J.W. Sakshaug \& R.A. Williams (eds.): SAGE Research Methods Foundations. Sage.

http://doi.org/10.4135/9781526421036831710

Quijano, A. 2008. Coloniality of Power, Eurocentrism and Latin America. Nepantla 1,3: 533 - 580.

Settler, F. \& M. Engh 2018. Religion and Migration in Africa and the African

Diaspora. Alternation Special Issue 22: 1 - 10.

https://doi.org/10.29086/2519-5476/2018/sp22a1

Sigamoney, J.R.F. 2018. Resilience of Somali Migrants: Religion and Spirituality among Migrants in Johannesburg. Alternation Special Issue 22: 81 - 102. https://doi.org/10.29086/2519-5476/2018/sp22a5

Sithole, T. 2014. Achille Mbembe: Subject, Subjection and Subjectivity. $\mathrm{PhD}$ thesis. Pretoria: University of South Africa.

Spickard, J. \& A. Adogame 2010. Introduction: Africa, the New African Diaspora, and Religious Transnationalism in a Global World. In Adogame,A. \& J. Spickard (eds.): Religion Crossing Boundaries: Transnational Religious and Social Dynamics in Africa and the New African Diaspora. Leiden: Brill. 
Tlostanova, M.V. \& W.D. Mignolo 2009. Pluritopic Hermeneutics, Transmodernity Thinking and Decolonial Philosophy. Encounters 1,1: 11 $-27$.

United Nations 2015. Combating Violence Against Migrants. New York: United Nations.

United Nations Children's Fund 2017. A Child is a Child: Protecting Children on the Move from Violence, Abuse and Exploitation. New York: UNICEF. United Nations High Commissioner for Refugees 2015. Promoting Tolerance, Dispelling Myths, Protecting Rights: An Evidence-Based Conversation on Migration. Geneva: UNHCR. 15 December. Available at: https://www.ohchr.org/EN/NewsEvents/Pages/DisplayNews.aspx?News $\underline{\mathrm{ID}=16889 \& \text { LangID }=\mathrm{E}}$

Wafawarova, R. 2015. The Curse of the Prosperity Gospel. The Herald, 15

February. Available at: www.hearlad.co.zw/theCurse-of-prosperitygospel/ (Accessed on: 20 February 2015.)

Williams, B.T. \& M. Brydon-Miller. 2004. Changing Directions: Participatory Action Research, Agency, and Representation. In Brown, S.G. \& S.I. Dobrin (eds.): Ethnography Unbound: From Theory Shock to Critical Praxis. Albany: State University of New York Press.

World Council of Churches 2017. Churches' Commitment to Children. Churches Uniting for Children in the Pilgrimage of Justice and Peace. Geneva: WCC, Unicef. Available at:

https://www.unicef.org/about/partnerships/files/wcc_commtmntchildren _UNICEF_ENG_PRODweb.pdf

Dr. Bekithemba Dube School of Education Studies Qwaqwa Campus University of the Free State Qwaqwa Dubeb@ufs.ac.za

Dr. Omodan Bunmi School of Education Studies QwaQwa Campus QwaQwa OmodanBI@ufs.ac.za 